Agro-Science Journal of Tropical Agriculture, Food, Environment and Extension Volume 9 Number 2 May 2010 pp. $104-110$

ISSN 1119-7455

\title{
ASSESSMENT OF THE QUALITY OF BOTTLED AND SACHET WATER SOLD IN NSUKKA TOWN
}

\author{
Onweluzo, J. C. and Akuagbazie, C. A. \\ Department of Food Science and Technology University of Nigeria, Nsukka
}

\begin{abstract}
:
The physical, chemical and microbiological qualities of 17 brands of bottled and sachet water sold in Nsukka town were evaluated to ascertain compliance with recommended standards by World Health Organization (WHO) and National Agency for Food and Drug Administration and Control (NAFDAC). Physical parameters like Total suspended and dissolved solids, turbidity and conductivity were determined by instrumental methods. Cationic and anionic constituents were determined by standard titrimetric and spectrophotometric methods. The study revealed that all the brands of water analyzed were physically and chemically wholesome and met the WHO standards (also adopted by NAFDAC). Four brands (24\%) of the water had total viable count above the recommended count of $1000 \mathrm{cfu} / \mathrm{ml}$ while $88 \%$ of the brands had coliform count above the recommended count of zero cfu/ml.
\end{abstract}

Key words: Bottled and sachet water, physical, chemical and microbiological qualities, coliform, total viable count.

\section{INTRODUCTION}

Water of good drinking quality is of basic importance to human physiology and man's continued existence depends very much on its availability. An average man (of $53 \mathrm{~kg}-63 \mathrm{~kg}$ body weight), requires about 3 litres of water in liquid and food daily to keep healthy (Wardlow et al., 2004). This fact apparently accounts for why water is regarded as one of the most indispensable substances in life and like air it is most abundant. However, despite its abundance, good quality drinking water is not readily available to man.

Unavailability of good quality drinking water is wide spread and this has serious health implications. In developing nations of the world, $80 \%$ of all diseases and over $30 \%$ of deaths are related to drinking water (Dada and Ntukekpo, 1997). According to Federal Ministry of Health statistics, only about $30 \%$ of Nigerians have access to portable water while the United Nations estimated that about 1.2 billion people all over the world lack access to portable water (Oyeku et al., 2001; Ajewole, 2005). Water is said to be portable when its physical, chemical and microbiological qualities conform to specified standards. To achieve such standards raw water is subjected to purification processes that range from simple longterm storage to enable sedimentation of some suspended solids to aeration, coagulation, flocculation, filtration and disinfection among other treatments (Ajewole, 2005). Variation in the combination of treatments required vary with the source and hence quality of the raw water (Macrae et al., 1993). Sources of water are many and varied, the level of contamination also vary, consequently a high degree of public health hazard can be associated with drinking water.The implication therefore, is that any drinking water sold to the public must be made wholesome and must meet WHO standards (Oyeku et al., 2001).

Unfortunately, the quality of water sold to the public in many places in Nigeria may not be said to be wholesome (Mendie, 2004). According to the Institute of Public Health Analyst (IPAN), $50 \%$ of the "pure water" sold in the streets of Lagos may not be fit for human consumption (Osibanjo et al., 2000). The possibility that the same situation may be applicable to other cities in the country prompted this work. The aim of the study was to evaluate the physical, chemical and microbial qualities of sachet and bottled water sold in Nsukka town and ascertain compliance with specified WHO/NAFDAC standards.

\section{MATERIALS AND METHODS}

A preliminary survey identified that 17 brands of bottled and sachet water were sold in Nsukka town at the time of the study. Three samples were collected from each brand from different locations of the town and used for the analyses. 
Quality Of Bottled and Sachet Water Sold in Nsukka Town

I titrated against $0.014 \mathrm{~N}$

\section{Physical Analyses}

Appearance and taste of the samples were evaluated subjectively using a 25 member semitrained panel and the standard operating procedure (SOP) on water analysis as specified by NAFDAC laboratory manual. Objective physical analyses were done using instrumental methods.

\section{Total Suspended Solids and Turbidity:}

The total suspended solids (TSS) content and turbidity of each water sample was determined with the hach portable colorimeter (Model DR/350) as described by APHA (1998). The instrument was zeroed with $25 \mathrm{ml}$ of deionised water which also served as the blank, subsequently the TSS was determined on $25 \mathrm{ml}$ of each water sample after $2 \mathrm{~min}$ vigorous shaking. The instrument was adjusted to measure turbidity by pressing "program 95" on the instrument's panel. The metre was zeroed with $10 \mathrm{ml}$ of deionised water (blank) and turbidity read directly from the instrument expressed in Nephelometic Turbidity Unit (NTU).

\section{Conductivity}

Conductivity was determined with a conductivity metre as described by APHA (1998). The probe of the instrument was rinsed first with distilled water and following rinsing with each water sample the probe was allowed to stay in the water sample for $1 \mathrm{~min}$ before recording the reading in micro siemen per $\mathrm{cm}\left(\mathrm{PSCM}^{1}\right)$. Determinations were done at $25^{\circ} \mathrm{C}$.

\section{Total Dissolved Solids (TDS)}

Total dissolved solids was determined with a TDS metre. The electrode was rinsed with deionised water followed by the water sample. The rinsed electrode was allowed to stabilize in the sample for 1 min after which the TDS value was read directly in $\mathrm{mg} / \mathrm{L}$.

\section{Chemical Analyses}

The $\mathrm{pH}$ of each water sample was determined with a $\mathrm{pH}$ metre after standardization with buffer solution.

\section{Determination of Anions Chloride}

Chloride was determined by the silver nitrate titrimetric method as described by APHA (1998). A $100 \mathrm{ml}$ volume of each sample in a conical flask was mixed with 3 drops of $10 \%$ potassium chromate indicator and a pinch of silver nitrate to a reddish tinge end point. Distilled water served as the blank. Concentration of chloride was calculated using the expression:

$$
\mathrm{Cl}(\mathrm{mg} / \mathrm{L})=\frac{(\mathrm{A}-\mathrm{B}) \times \mathrm{N} \times 35.45}{\text { Vol. of sample }} \times 1000
$$

Where $\mathrm{A}=$ Titre value of sample

$\mathrm{B}=$ Titre value of distilled water

$\mathrm{N}=$ Normality of Silver nitrate

\section{Total Hardness}

Total hardness was determined by the ethylenediamine tetra acetic acid (EDTA) titrimetric method as described by APHA (1998). Fifty milliliters of each water sample in a $250 \mathrm{ml}$ flask was mixed with $1 \mathrm{ml}$ of $\mathrm{NH}_{4} \mathrm{Cl}-\mathrm{NH}_{4} \mathrm{OH}$ buffer and $2 \mathrm{ml}$ of solochrome black "T" indicator and titrated with 0.02N EDTA to a blue end point. Total hardness was calculated with the expression:

Total hardness $(\mathrm{mg} / \mathrm{L})=\frac{\mathrm{A} \times 100}{50}$

Where $\mathrm{A}=$ Titre value

\section{Phosphate}

Phosphate was determined by the molybdate spectrophotometric method described by APHA (1998). Standard solutions of $\mathrm{KH}_{2} \mathrm{PO}_{4}$ were prepared to contain $0,2,4,6,8$ and $10 \mathrm{mg} / \mathrm{L}$ of phosphate. A volume $(15 \mathrm{ml})$ of each water sample and the standard solution in $50 \mathrm{ml}$ volumetric flask was mixed with $1 \mathrm{ml}$ of ammonium molybdate reagent, 3 drops of stannous chloride reagent and diluted to $50 \mathrm{ml}$ with distilled water. Absorbance values of the water samples and standard solutions were read at $650 \mathrm{~nm}$ using spectronic 21 spectrophotometer. A standard curve was prepared with the absorbance values and the concentration of phosphate in the sample was extrapolated from the standard curve.

\section{Nitrate}

Nitrate was determined by the spectrophotometric sodium salicylate method. Standard solutions of potassium nitrate were prepared $(0$ to $5 \mathrm{mg} / \mathrm{L})$ and $10 \mathrm{ml}$ of each standard solution was mixed with $1 \mathrm{ml}$ of sodium salicylate solution, $2 \mathrm{ml}$ of concentrated Sulphuric acid and allowed to stand for $15 \mathrm{~min}$. A $15 \mathrm{ml}$ volume of distilled water and $15 \mathrm{ml}$ of sodium tatarate solution were added to each sample and absorbance of the yellow colour developed was read at $420 \mathrm{~nm}$. A calibration curve was plotted with the absorbance values of the standard and the 
concentration $(\mathrm{mg} / \mathrm{L})$ of nitrate in the samples was extrapolated from the standard curve.

\section{Sulphate}

Sulphate was determined by a titrimetric method. A $2 \mathrm{ml}$ volume of benzidine hydrochloride was added to $250 \mathrm{ml}$ of each water sample with continuous mixing for $2 \mathrm{~min}$. The precipitate was removed by filtration and the filtrate was titrated against $0.05 \mathrm{M}$ Sodium hydroxide to a permanent pink end point using 3 drops of phenolphhthalein indicator. Distilled water served as the blank. Concentration of sulphate was calculated with the expression Sulphate $(\mathrm{mg} / \mathrm{L})=$ sample titre - blank titre $\times 9.6$

\section{Determination of Cations}

Cations, calcium, sodium, and potassium were determined by standard AOAC (1984) methods, using the flame photometer. Iron was determined by a colorimetric method using Hach (model DR/850 Japan) colorimeter and "ferro ver iron powder pillow reagent" as described by the Hach colorimeter manual.

\section{Microbiological Analyses}

The microbiological quality of the water samples was determined using total viable count and total coliform count as indices. Total viable count was determined by the pour plate method. Ten fold dilution of the water sample was prepared and $0.1 \mathrm{ml}$ of the dilution was poured on nutrient agar plates and incubated at $37^{\circ} \mathrm{C}$ for $24 \mathrm{~h}$. The plates were examined for growth after incubation and developed colonies counted using a digital colony counter (Gallenkamp, England). Total coliform count was determined on each sample by plating presumptive positive samples on Mac Conkay agar. Incubation was done at $35^{\circ} \mathrm{C}$ for 48 h.

\section{Statistical Analysis}

Determinations were done in 3 replicates. Data were subjected to analysis of variance and the least significant difference (LSD) test was used to separate differences between means.

\section{RESULTS AND DISCUSSION}

At the time of the study, there were seventeen (17) brands of sachet and bottled water sold in Nsukka town out of which 11 brands (about $65 \%$ ) were produced within Nsukka town while 6 brands were produced outside the town.

\section{Physical Characteristics}

Table 1 shows the results of the physical characteristics of sachet and bottled water sold in Nsukka town. All the brands of sachet and bottled water evaluated met the recommended WHO (1984) standards (which is adopted by NAFDAC) for appearance, and taste. The sachet samples showed higher $(0.50-4.25 \mathrm{mg} / \mathrm{L})$ levels of total dissolved solids (TDS $\mathrm{mg} / \mathrm{L}$ ) than the bottled (0.18 $-2.10 \mathrm{mg} / \mathrm{L}$ ) samples. However, TDS of all the water samples is within the standard $(500 \mathrm{mg} / \mathrm{L})$ recommended by WHO and FAFDAC. Total dissolved solid is a measure of the level of dissolved solid in water and it influences the taste of drinking water. All sachet and bottled water sold in Nsukka town have zero total suspended solid (TSS) and zero turbidity. Turbidity in water results from the presence of suspended solids therefore the observed zero turbidity is also a reflection of the zero TSS result. Evidently, all the bottled and sachet water sold in Nsukka town have high standard of clarity indicating that the filtration processes were adequately done in all the production centres

Bottled water sold in Nsukka town have conductivity values that ranged from $0.5 \mathrm{\mu SCM}^{-1}$ to $2.54 \mathrm{\mu SCM}^{-1}$ while the sachet brands showed conductivity value range of $1.37 \mu \mathrm{SCM}^{-}{ }^{1}$ to 7.18 $\mu \mathrm{SCM}^{-}{ }^{1}$. The bottled water samples showed similar pattern of variation in conductivity as in TDS with the sachet samples having higher conductivity than the bottled samples. Conductivity of the water samples was within the standard recommended $\left(1000 \mu \mathrm{SCM}^{-}{ }^{1}\right)$ by WHO and NAFDAC. All the bottled and sachet water sold in Nsukka town met the recommended WHO/NAFDAC standards in terms of physical characteristics. Oyeku et al. (2001) and Nwosu and Ogueke (2004) made similar observations in the physical characteristics of sachet water sold in Lagos and Owerri metropolis, respectively.

\section{Chemical Characteristics}

Table 2 shows the chemical characteristics of sachet and bottled water sold in Nsukka town. The sachet samples showed a wider $\mathrm{pH}$ range $(5.83$ 6.55) than the bottled samples. All the bottled samples and about $36.4 \%$ of the sachet samples showed $\mathrm{pH}$ values within the range recommended $(6.5-8.5)$ by WHO and NAFDAC.The chemical characteristics of all the brands of water evaluated were within the range of standard values recommended for chloride, total hardness, phosphate, nitrate, sulphate, iron, potassium, sodium and calcium by WHO and NAFDAC. The implication of this result is that the processors of these brands of water obtain raw water from chemically good sources and adopt standard 
Quality Of Bottled and Sachet Water Sold in Nsukka Town

Table 1: Selected Physical Characteristics of Sachet and Bottled Water Sold in Nsukka Town

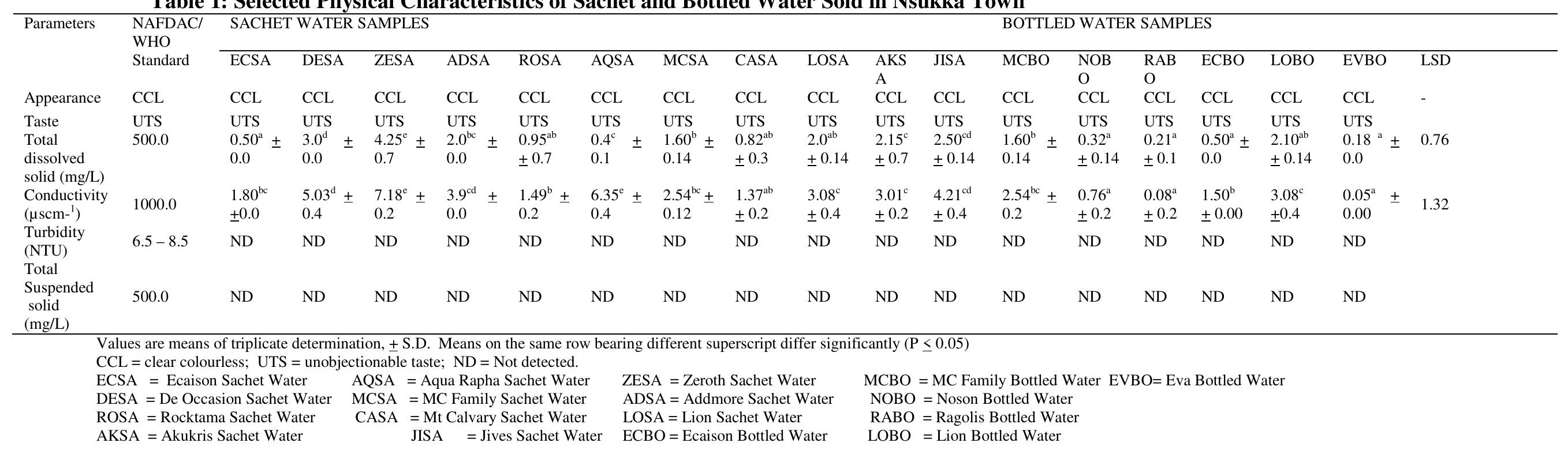


operating procedures for chemical water treatment. Oyeku et al, (2001) and Nwosu and Ogueke (2004) also reported good chemical characteristics of sachet water sold in Lagos and Owerri metropolis respectively. Among the bottled water samples, MCBO and ECBO brands had the highest $(7.89 \mathrm{mg} / \mathrm{L})$ and lowest $(1.04 \mathrm{mg} / \mathrm{L})$ levels of chloride. Among the sachet samples ROSA had the highest $(9.88 \mathrm{mg} / \mathrm{L})$ level while ECSA and AQSA had the lowest $(1.04 \mathrm{mg} / \mathrm{L})$ level of chloride. High level of chloride is known to impart taste to portable water particularly when sodium is the predominant cation (APHA, 1998). Apparently the level of residual chloride observed in the samples used for this study was not high enough to impact on the taste of the samples, since there was no salty or objectionable taste identified in any of the water samples. ROSA and AKSA brands of sachet water had the highest $(6.60 \mathrm{mg} / \mathrm{L})$ total hardness expressed as $\mathrm{CaCO}_{3}$ while LOSA and ECSA brands had the least total hardness (2.0 $\mathrm{mg} / \mathrm{L}$ ). Among the bottled samples, NOBO brand had the highest $(3.6 \mathrm{mg} / \mathrm{L})$ total hardness while RABO and EVBO brand had very low $(0.8 \mathrm{mg} / \mathrm{L})$ total hardness.

However, the level of total hardness in all the brands of water evaluated is within the range of total hardness $(500 \mathrm{mg} / \mathrm{L})$ recommended by WHO and NAFDAC. According to APHA (1998), calcium contributes appreciably to total hardness but in this study ROSA brand which had a relatively high total hardness $(6.8 \mathrm{mg} / \mathrm{L})$ showed lowest $(0.57 \mathrm{mg} / \mathrm{L})$ calcium content when compared with the level in other brands. The levels of other anions, phosphate, nitrate and sulphate in all the brands of water evaluated met the recommended standards for portable water (Table 2). Among the sachet samples, DESA brand had the highest $(\mathrm{P} \leq 0.05)$ level of phosphate $(2.19 \mathrm{mg} / \mathrm{L})$ and nitrate $(5.33 \mathrm{mg} / \mathrm{L})$ while ROSA brand contains the highest level $(\mathrm{P} \leq 0.05)(2.02$ $\mathrm{mg} / \mathrm{L}$ ) of sulphate.
Bottled NOBO showed highest levels of phosphate $(2.7 \mathrm{ml} / \mathrm{L})$ and sulphate $(1.9 \mathrm{mg} / \mathrm{L})$ while $\mathrm{LOBO}$ brand had the highest $(3.5 \mathrm{mg} / \mathrm{L})$ nitrate content. Anions, phosphate, nitrate and sulphate were not detected in EVBO and RABO bottled brands. There were variations in the levels of the cations, iron, potassium, sodium and calcium in the different brands of water evaluated. The brand ECSA, ECBO, AQSA, RABO and EVBO had comparable $(\mathrm{P}>0.05)$ levels $(0.07 \mathrm{mg} / \mathrm{L})$ of iron while LOSA, LOBO, DESA, ADSA and MCSA brands had comparable $(\mathrm{P}>0.05)$ levels $(0.03-$ $0.04 \mathrm{mg} / \mathrm{L}$ ) of iron.

ROSA, LOSA, LOBO, RABO and EVBO brands of water had less than $1 \mathrm{mg} / \mathrm{L}$ concentration of sodium, while other brands had relatively higher concentration of sodium. Although the level of sodium in these brands of water was within the recommended limit $(<20$ $\mathrm{mg} / \mathrm{L}$ ) this level of sodium can lead to a high $\mathrm{Na} / \mathrm{K}$ and $\mathrm{Na}$ /total cation ratio which may be of great concern from the perspective of human pathology (NRC, 1989; APHA, 1998). According to NRC (1989), a $\mathrm{Na} / \mathrm{K}$ ratio of 1 or less than 1 is preferably recommended. Of all the water sold in Nsukka at the time of the study only LOSA, LOBO, JISA and EVBO (constituting about 24\% of all the water sold in Nsukka) have $\mathrm{Na} / \mathrm{K}$ ratio less than 1. Since according to Kleiner (1999) drinking water can contribute up to $10 \%$ of our sodium intake, it may be pertinent to advocate that levels of sodium in drinking (bottled and sachet) water be declared on labels so as to alert consumers on sodium restricted diets. However, despite the fact that sodium seem to be the predominant cation in about $76 \%$ of the water brands evaluated no salty taste was detected in any of the samples during the subjective test.

Calcium level in CASA, RABO, ROSA and EVBO brands was less than 1 while about $76 \%$ of the water brands showed relatively higher (more than 1) level of calcium content. National Research Council (NRC, 1989) noted that calcium is one of the essential dietary minerals that drinking water usually supplies. 
Table 2: Selected Chemical Characteristics of Sachet and Bottled Water Sold in Nsukka Town

\begin{tabular}{|c|c|c|c|c|c|c|c|c|c|c|c|c|c|c|c|c|c|c|c|}
\hline \multirow[t]{2}{*}{ Parameters } & \multirow{2}{*}{$\begin{array}{l}\text { NAFDA } \\
\text { C/ WHO } \\
\text { Standard }\end{array}$} & \multicolumn{11}{|c|}{ SACHET WATER SAMPLES } & \multicolumn{7}{|c|}{ BOTTLED WATER SAMPLES } \\
\hline & & ECSA & DESA & ZESA & ADSA & ROSA & AQSA & MCSA & CASA & LOSA & AKSA & JISA & MCBO & NOBO & RABO & ECBO & LOBO & EVBO & LSD \\
\hline $\mathrm{pH}$ & $6.5-8.5$ & $6.52^{\mathrm{ab}}$ & $5.83^{\mathrm{a}}$ & $6.35^{\mathrm{a}}$ & $5.97^{\mathrm{a}}$ & $6.40^{\mathrm{a}}$ & $6.55^{\mathrm{ab}}$ & $6.48^{\mathrm{ab}}$ & $6.24^{\mathrm{a}}$ & $6.23^{\mathrm{a}}$ & $6.46^{\mathrm{a}}$ & $6.44^{\mathrm{a}}$ & $6.50^{\mathrm{ab}}$ & $6.49^{\mathrm{ab}}$ & $6.62^{\mathrm{b}}$ & $6.51^{\mathrm{ab}}$ & $6.53^{\mathrm{ab}}$ & $6.70^{\mathrm{b}}$ & 0.64 \\
\hline Chloride (mg/L) & 600 & $1.04^{\mathrm{a}}$ & $8.39^{\mathrm{bc}}$ & $4.82^{\mathrm{b}}$ & $7.10^{\mathrm{b}}$ & $9.88^{\mathrm{c}}$ & $1.04^{\mathrm{a}}$ & $7.85^{\mathrm{bc}}$ & $5.91^{\mathrm{b}}$ & $4.07^{\mathrm{ab}}$ & $8.93^{\mathrm{bc}}$ & $7.99^{\mathrm{bc}}$ & $7.89^{\mathrm{bc}}$ & $7.00^{\mathrm{b}}$ & $3.72^{\mathrm{ab}}$ & $1.04^{\mathrm{a}}$ & $4.02^{\mathrm{ab}}$ & $2.73^{\mathrm{a}}$ & 3.42 \\
\hline $\begin{array}{l}\text { Total hardness } \\
(\mathrm{mg} / \mathrm{L})\end{array}$ & 500 & $2.0^{\mathrm{a}}$ & $4.40^{\mathrm{b}}$ & $3.6^{\mathrm{b}}$ & $4.40^{\mathrm{b}}$ & $6.80^{\mathrm{c}}$ & $3.0^{\mathrm{ab}}$ & $3.6^{\mathrm{b}}$ & $2.80^{\mathrm{ab}}$ & $2.0^{\mathrm{a}}$ & $6.80^{\mathrm{c}}$ & $5.2^{\mathrm{bc}}$ & $3.0^{\mathrm{ab}}$ & $3.6^{\mathrm{b}}$ & $0.8^{\mathrm{a}}$ & $2.0^{\mathrm{a}}$ & $2.4^{\mathrm{a}}$ & $0.8^{\mathrm{a}}$ & 1.83 \\
\hline Phosphate (mg/L) & 50 & $0.62^{\mathrm{ab}}$ & $2.19^{\mathrm{cd}}$ & $1.40^{\mathrm{c}}$ & $0.19^{\mathrm{a}}$ & $1.49^{\mathrm{c}}$ & $0.80^{\mathrm{b}}$ & $1.20^{\mathrm{bc}}$ & $1.85^{\mathrm{c}}$ & $1.18^{\mathrm{bc}}$ & $0.18^{\mathrm{a}}$ & $1.0^{\mathrm{b}}$ & $1.40^{\mathrm{c}}$ & $2.70^{\mathrm{d}}$ & 0.0 & $0.67^{\mathrm{ab}}$ & $1.35^{\mathrm{c}}$ & 0.0 & 0.54 \\
\hline Nitrate $(\mathrm{mg} / \mathrm{L})$ & 45 & $0.40^{\mathrm{a}}$ & $5.33^{\mathrm{cd}}$ & $2.20^{\mathrm{b}}$ & $4.80^{\mathrm{c}}$ & $1.70^{\mathrm{ab}}$ & $0.80^{\mathrm{a}}$ & $1.00^{\mathrm{a}}$ & $2.80^{\mathrm{b}}$ & $3.80^{\mathrm{bc}}$ & $0.90^{\mathrm{a}}$ & $2.30^{\mathrm{b}}$ & $1.30^{\mathrm{a}}$ & $2.60^{\mathrm{b}}$ & 0.0 & $0.40^{\mathrm{a}}$ & $3.5^{\mathrm{bc}}$ & 0.0 & 1.46 \\
\hline Sulphate (mg/L) & $5-250$ & $0.24^{\mathrm{a}}$ & $1.63^{\mathrm{bc}}$ & $1.34^{\mathrm{b}}$ & $1.82^{\mathrm{bc}}$ & $2.02^{\mathrm{c}}$ & $0.77^{\mathrm{ab}}$ & $1.34^{\mathrm{b}}$ & $2.30^{\mathrm{cd}}$ & $0.86^{\mathrm{ab}}$ & $0.24^{\mathrm{a}}$ & $1.14^{\mathrm{b}}$ & $1.54^{\mathrm{bc}}$ & $1.92^{\mathrm{c}}$ & 0.0 & $0.38^{\mathrm{a}}$ & $0.67^{\mathrm{a}}$ & 0.0 & 0.54 \\
\hline Iron $(\mathrm{mg} / \mathrm{L})$ & 0.3 & $0.06^{\mathrm{b}}$ & $0.03^{\mathrm{a}}$ & $0.07^{\mathrm{b}}$ & $0.04^{\mathrm{a}}$ & $0.19^{\mathrm{e}}$ & $0.06^{\mathrm{b}}$ & $0.04^{\mathrm{a}}$ & $0.11^{\mathrm{c}}$ & $0.03^{\mathrm{a}}$ & $0.10^{\mathrm{c}}$ & $0.09^{\mathrm{c}}$ & $0.05^{\mathrm{ab}}$ & $0.17^{\mathrm{d}}$ & $0.07^{\mathrm{b}}$ & $0.07^{\mathrm{b}}$ & $0.04^{\mathrm{a}}$ & $0.07^{\mathrm{b}}$ & 0.02 \\
\hline Potassium (mg/L) & $<12$ & $2.29^{\mathrm{cd}}$ & $0.95^{\mathrm{ab}}$ & $0.58^{\mathrm{a}}$ & $1.62^{\mathrm{bc}}$ & $0.83^{\mathrm{a}}$ & $0.79^{\mathrm{a}}$ & $1.37^{\mathrm{b}}$ & $0.56^{\mathrm{a}}$ & $1.55^{\mathrm{bc}}$ & $1.74^{\mathrm{bc}}$ & $1.97^{\mathrm{c}}$ & $1.34^{\mathrm{b}}$ & $2.35^{\mathrm{cd}}$ & $0.44^{\mathrm{a}}$ & $2.29^{\mathrm{cd}}$ & $1.54^{\mathrm{bc}}$ & $0.60^{\mathrm{a}}$ & 0.48 \\
\hline Sodium (mg/L) & $<20$ & $5.69^{\mathrm{de}}$ & $6.34^{\mathrm{e}}$ & $4.85^{\mathrm{d}}$ & $3.08^{\mathrm{bc}}$ & $0.98^{\mathrm{a}}$ & $2.26^{\mathrm{b}}$ & $6.74^{\mathrm{e}}$ & $7.42^{\mathrm{e}}$ & $0.93^{\mathrm{a}}$ & $3.36^{\mathrm{c}}$ & $1.68^{\mathrm{b}}$ & $6.73^{\mathrm{e}}$ & $5.44^{\mathrm{d}}$ & $0.48^{\mathrm{a}}$ & $5.68^{\mathrm{de}}$ & $0.94^{\mathrm{a}}$ & $0.56^{\mathrm{a}}$ & 1.02 \\
\hline Calcium (mg/L) & $10-200$ & $1.38^{\mathrm{b}}$ & $1.76^{\mathrm{c}}$ & $1.24^{\mathrm{b}}$ & $1.72^{\mathrm{bc}}$ & $0.57^{\mathrm{a}}$ & $1.46^{\mathrm{bc}}$ & $1.15^{\mathrm{ab}}$ & $0.82^{\mathrm{a}}$ & $1.0^{\mathrm{ab}}$ & $1.91^{\mathrm{c}}$ & $1.27^{\mathrm{b}}$ & $1.16^{\mathrm{ab}}$ & $1.33^{\mathrm{b}}$ & $0.83^{\mathrm{a}}$ & $1.37^{\mathrm{b}}$ & $1.02^{\mathrm{ab}}$ & $0.65^{\mathrm{a}}$ & 0.36 \\
\hline $\mathrm{Na} / \mathrm{K}$ ratio & - & 2.48 & 6.67 & 8.36 & 1.90 & 1.18 & 2.86 & 4.92 & 13.25 & 0.6 & 1.93 & 0.85 & 5.02 & 2.31 & 1.09 & 2.48 & 0.6 & 0.0 & \\
\hline $\mathrm{Na} /$ Cation ratio & - & 1.53 & 2.31 & 2.57 & 0.91 & 0.62 & 0.98 & 2.63 & 4.98 & 0.36 & 0.89 & 0.52 & 2.64 & 1.41 & 0.36 & 1.52 & 0.36 & 0.44 & \\
\hline
\end{tabular}

Values are means of triplicate determinations. \pm S.D. Means on the same row bearing different superscript differ significantly $(\mathrm{P} \leq 0.05)$.

ECSA = Ecaison Sachet Water AQSA = Aqua Rapha Sachet Water ZESA = Zeroth Sachet Water MCBO = MC Family Bottled Water EVBO= Eve Bottled Water

DESA $=$ De Occasion Sachet Water MCSA $=$ MC Family Sachet Water ADSA $=$ Addmore Sachet Water $\quad$ NOBO $=$ Noson Bottled Water

ROSA $=$ Rocktama Sachet Water CASA $=$ Mt Calvary Sachet Water LOSA $=$ Lion Sachet Water $\quad$ RABO $=$ Ragolis Bottled Water

$\mathrm{AKSA}=$ Akukris Sachet Water $\quad \mathrm{JISA}=$ Jives Sachet Water $\quad$ ECBO $=$ Ecaison Bottled Water $\quad$ LOBO $=$ Lion Bottled Water

Table 3: Selected Microbiological Characteristics of Sachet and Bottled Water Sold in Nsukka Town

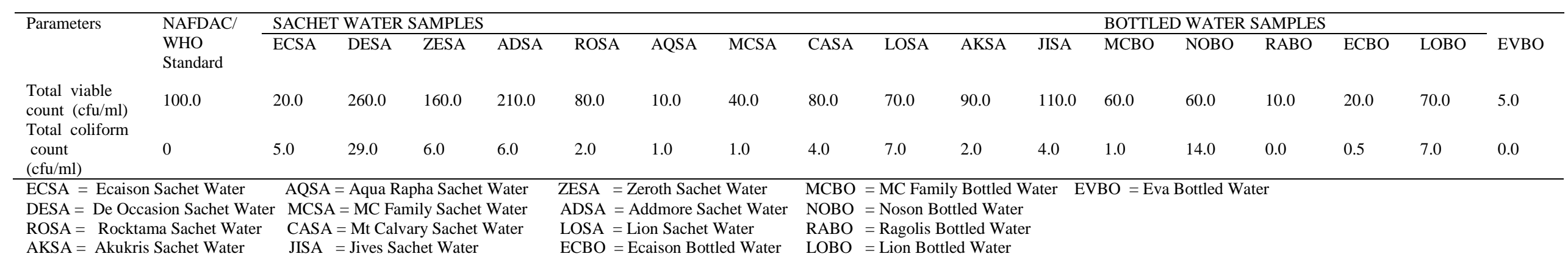




\section{MICROBIOLOGICAL CHARACTERISTICS:}

Results of the microbiological analyses (Table 3) showed that 4 brands of water (DESA, ZESA, ,ADSA and JISA) had viable plate counts above the $100 \mathrm{CFU} / \mathrm{ml}$ standard recommended by WHO and NAFDAC. All the brands of water except RABO and EVBO brands, which had zero content, DESA and NOBO which had 29.0 and 14.0 contents respectively had total coliform counts ranging from 1.0 to $7.0 \mathrm{CFU} / \mathrm{ml}$ while the recommended standard is zero CFU/ml. Since coliform is indicative of feacal contamination, the implication is that $88 \%$ of the water sold in Nsukka town were produced under very poor sanitary conditions or that the water were "improperly handled" (Banwart, 2004). Edema et al (2001) similarly observed that many brands of water sold in Abeokuta did not meet WHO microbiological standards. Feacal contamination of drinking water has very serious health implications (Banwart, 2004).

\section{CONCLUSION:}

It was evident from the study that sachet and bottled water sold in Nsukka town at the time of the study met the recommended standards for physical and chemical qualities but about $88 \%$ of the water brands were microbiologically unwholesome. Since microbiological quality of water is a hidden quality attribute that impact seriously on public health, it is pertinent that the activities of regulatory agencies be intensified to ensure compliance with standard to avert public health hazards.

\section{REFERENCES}

AOAC (1984). Official Methods of Analysis, 14th ed. Association of Official Analytical Chemists, Washington, D.C.

APHA (1998). Standard Methods for the Examination of Water and Waste Water. American Public Health Association, Washington, D.C.

Ajewole, I.A. (2005). Water an Overview, Food Forum, A Publication of the Nigerian Institute of Food Science and Technology, September 2005, 4(1): 15.

Banwart, G.J. (2004). Basic Food Microbiology, 2nd ed. Chapman \& Hall Inc., New York, $751 \mathrm{pp}$.

Dada, A. and D.S. Ntukekpo (1997). Pure Water: How Safe? Ultimate Water Technology and Environment, 1(3): $8-11$.
Edema, M.O.; Omemu, A.M. and Fapetu, O.M. (2001). Microbiology and PhysicoChemical Analysis of Different Sources of Drinking Water in Abeokuta, Nigeria. Nigerian Journal of Microbiology, 15(1): $57-61$.

Kleiner, S.M. (1999). Water: An Essential but Overlooked Nutrient. Journal of the American Dietetic Association, 99: 200 206.

Macrae, R.; Robinson, R.K. and Sodler, M.T. (1993). Encyclopedia of Food Science. Food Technology and Nutrition. Academic Press Publishers, London. Pp. 1073 - 1077.

Mendie, U. (2004). Cyclical Growth of Contaminants in Drinking Water Packaged in Polythene Bags. Nigerian Journal of Pharmacy 40: 398 - 399.

NRC (1989). National Research Council, Food and Nutrition Board. Recommended Dietary Allowances, 10th ed. Washington, D.C. National Academy of Sciences.

Nwosu, J.N. and Ogueke, C.C. (2004). Evaluation of Sachet Water Samples in Owerri Metropolis. Nigerian Food Journal, 22: $164-170$.

Osibanjo, O.; Ajayi, S.; Adebiyi, F. and Akinyanju, P. (2000). Public Analysis Reporting System as Applied to Environmental Issues. IPAN News, A Publication of the Institutue of Public Analysts 1(3): 10.

Oyeku, O.M.; Omowumi, O.T.; Kupoluyi, C.F. and Toye, E.O. (2001). Wholesomeness Studies of Water Produced and Sold in Plastic Sachets (Pure Water) in Lagos Metropolis. Nigerian Food Journal, 19: 63 $-69$.

WHO (1984). World Health Organization, Guidelines for the Examination of Drinking Water, 1: 5 - 39.

Wordlaw, G.M.; Hampl, J.S. and Disilvestro, R.A. (2004). Perspectives in Nutrition. 6th ed. McGraw-Hill Publishers, New York, ,pp. $372-412$. 